\title{
Disease as a Factor in the African Archaeological Record
}

\author{
Susan Pfeiffer
}

Published online: 25 August 2020

(C) Springer Science+Business Media, LLC, part of Springer Nature 2020

\begin{abstract}
It is clear from their natural histories that various kinds of diseases would have affected African communities in the distant past. Climatic factors may have reduced the impact of plague-like epidemics across much of the continent. Because of the link between environment and disease vectors, the presence of a disease may have been a stimulus for some group movements in the African past. Evidence of the direct effects of diseases on human populations is generally elusive. Paleopathologists can identify some endemic diseases, but evidence from Africa is sparse. Paleogenomics research can also identify some (not all) endemic and epidemic disease vectors. Recent African aDNA discoveries of inherited resistance to endemic diseases suggest that future paleogenomic research may help us learn much more about the impact of diseases on the African past.
\end{abstract}

Résumé Il ressort clairement de leur histoire naturelle que divers types de maladies auraient affecté les communautés africaines dans un passé lointain. Les

\footnotetext{
S. Pfeiffer

Department of Anthropology, University of Toronto, 19 Ursula Franklin Street, Toronto M5S 2S2, Canada

S. Pfeiffer

Department of Archaeology, University of Cape Town, Cape Town, South Africa

S. Pfeiffer $(\bowtie)$

Center for the Advanced Study of Human Paleobiology, George

Washington University, Washington, DC, USA

e-mail: susan.pfeiffer@utoronto.ca
}

facteurs climatiques peuvent avoir réduit l'impact des épidémies de type peste sur une grande partie du continent. En raison du lien entre l'environnement et les vecteurs de maladies, la présence d'une maladie peut avoir été un stimulant pour certains mouvements de groupe dans le passé africain. Les preuves des effets directs des maladies sur les populations humaines sont généralement insaisissables. Les paléopathologistes peuvent identifier certaines maladies endémiques, mais les preuves provenant d'Afrique sont rares. La recherche en paléogénomique peut également identifier certains (pas tous) des vecteurs de maladies endémiques et épidémiques. Les découvertes récentes de l'ADN fossile en Afrique sur la résistance héréditaire aux maladies endémiques suggèrent que les futures recherches paléogénomiques pourraient nous aider à en apprendre beaucoup plus sur l'impact des maladies sur le passé africain.

Keywords Bioarchaeology · Climate - Disease · Migration $\cdot$ Paleopathology $\cdot$ Paleogenomics

Bioarchaeologists and paleopathologists who study ancient human skeletons acknowledge that cause of death is rarely discernable. We repeat this mantra, and we know the fact is unlikely to change, yet the quest to determine cause of death drives the development of new theories and new methods. This quest is now amplified by the broad public interest in epidemics created by the current COVID-19 pandemic. There are many webbased resources about past epidemics (see notes below 
for some examples). ${ }^{1}$ Why are the examples from historical documents, rather than archaeological evidence? Why are none from the continent of Africa, especially outside the Nile Valley?

The lack of time depth to the story of global epidemics reflects several factors. For virulent pathogens to thrive, people must live in close proximity to one another, spend significant time indoors, and must be relatively settled. Cold weather encourages long-term indoor activities and layers of clothing, which in turn keep disease vectors like fleas, lice, and rodents nearby. When mortality suddenly spikes in a community, the normal practices of honoring the dead and ceremoniously laying them to rest may be abandoned. The plague pits of Europe represent such a modification of normal practice. In more dispersed communities, survivors may choose to flee the epidemic mayhem, leaving little or no evidence of their motives. Infectious pathogens that kill their targets quickly do not leave tell-tale changes to the skeleton. All these factors mitigate against seeing archaeological evidence of past epidemics in subSaharan Africa.

A pathogen that is virulent enough to create epidemic circumstances may arise quickly when a new mutation allows it to jump from non-human to human. The field of palaeogenomics (genome-wide ancient DNA analysis) has made great strides in revealing the natural history of disease vectors that have affected humans for centuries. Some pathogens, like Mycobacterium tuberculosis (TB), have had long and complex relationships with humans. Several regional strains of TB have been identified. Although some degree of immunity to an endemic regional strain can develop over time, the introduction of new strains can create distress when people migrate and colonize new lands. This occurred when Europeans entered the Americas in large numbers, introducing their form of TB to continents where people had been co-existing rather successfully with a different strain. Ancient pathogenic bacilli have been found in bone from many archaeological contexts (Roberts and

\footnotetext{
${ }^{1}$ Web resources on past epidemics:

The Black Death: What bubonic plague reveals about COVID-19 coronavirus pandemic

https://www.medicinenet.com/script/main/art. asp?articlekey $=229027$

The reputed Plague Pits of London

h t t p s : / / w w w. h i s t o r i c - u k.

com/HistoryMagazine/DestinationsUK/LondonPlaguePits/

Pandemics that changed history

https://www.history.com/topics/middle-ages/pandemics-timeline
}

Buikstra 2003). One well-received theory suggests an African origin for human pathogenic TB, about 70,000 years ago. This is based on genetic relationships among seven major lineages of the modern disease (Galagan 2014). To date, the archaeological evidence for this is limited to Egypt, Nubia, and perhaps artwork from North Africa (Roberts and Buikstra 2003). The earliest skeletal evidence of human TB in sub-Saharan Africa dates to the period of European colonization (Campbell et al. 2013).

The developing story of how Yersinia pestis arose and abated multiple times in Europe and Asia during the past 5000 years is fascinating (Rascovan et al. 2019). Paleogenomics has been central to that exploration. Other diseases have tackled humans more recently. The measles virus appears to have jumped from Rinderpest morbillivirus only about two millennia ago (Ho and Duchêne 2020). Several of the most fearsome pathogens, like cholera and smallpox (variola) virus, have not been amenable to paleogenomic methods - at least not yet. Paleopathologists have suggested that among communities with some "herd immunity," there is evidence of bone lesions associated with smallpox suffered during childhood (Darton et al. 2013), but case reports come mainly from Europe.

What about evidence from Africa? Archaeological discoveries of well-preserved human skeletons are generally rare across the continent, thanks to various combinations of climatic heat, humidity, and mortuary practices. The few instances of multiple human bodies in close proximity, like those at Jebel Sahaba (Anderson 1968; Wendorf 1968) and Nataruk (Lahr et al. 2016; Stojanowski et al. 2016), have been attributed to interpersonal violence rather than natural causes like food poisoning, starvation, or epidemic deaths. Burials associated with monuments are known from many regions, from Ethiopia to Senegal (Phillipson 2005), and burials have been excavated in association with Iron Age settlements. Poor bone preservation is often reported, but where analyses have been possible, the demographic profiles seem consistent with normal mortality patterns (as an example, Gibbon et al. 2014), rather than a catastrophic pattern. It seems unlikely that direct evidence of epidemic deaths, like plague pits, will be found. However, glimpses of the story of humans and their pathogens are available through palaeogenomics. The evidence is strongest from the southern part of the continent. Bone preservation is sometimes excellent there, thanks to a drier, cooler climate, as well as the 
use of dry rock shelters and sandy beaches for interments.

While the focus of human palaeogenomics research is population structure, genetic material associated with disease resistance helps to inform that exploration. Schlebusch and colleagues explored the genomes of seven curated skeletons from KwaZulu-Natal: three San hunter-gatherers and four Iron Age farmers (Schlebusch et al. 2017). Their scans of single nucleotide polymorphisms (SNPs) included a genetic variant protective against Plasmodium vivax (one of five parasites that cause malaria in humans) and sleeping sickness. Three of the farmers showed the presence of at least one Duffy null allele, which has a strong protective effect against malaria. Two of the Iron Age farmers carried a variant protective against African sleeping sickness. None of the hunter-gatherers showed either of these traits. Among the skeletons studied, the bestpreserved aDNA came from a San boy, about 6 years old when he died. He had been ill for some time, based on changes to his bone. We think he was affected by schistosomiasis, a parasitic infection that is present in that part of KwaZulu-Natal today (Pfeiffer et al. 2019).

More recent work has identified the anti-malarial variant in an Early Iron Age man (Xaro, 1400 BP) from Botswana (Wang et al. 2020). Selection for human resistance to malaria and sleeping sickness would have occurred in tropical and subtropical parts of the continent, with those genes retained when subsequent generations moved south into a more temperate zone. Resident communities whose ancestors had adapted to those more temperate climes would have had no need for resistance to diseases that did not thrive locally, but they could carry the gene as a marker of their ancestry. It seems likely that the identification of disease resistance genes is going to be a helpful adjunct to other approaches for tracking the Bantu expansion.

The exploration of human genetic adaptations for disease resistance has even ventured into the topic of absence of evidence. Genome patterns among living San groups suggest a direct relationship between exposure to outside populations (hence, introduced infectious diseases) and the presence of disease immunity genes (Owers et al. 2017). This is a reminder that disease is yet another factor that would have influenced the dynamics between resident communities and incomers. In southernmost Africa, the arrivals of Khoi, Bantu-speaking peoples, and Europeans would each have brought their pathogen profile.
New lab methods and new sampling strategies are fueling an expansion of palaeogenomics into Africa. Sampling the very dense bone that surrounds the inner ear - the petrous pyramid of the temporal bone - has improved aDNA yield from ancient skeletons of diverse geographic origins (Pinhasi et al. 2015). Nevertheless, due to climatic conditions and a host of other factors (Prendergast and Sawchuk 2018), Africa is still underrepresented in these studies (Brunson and Reich 2019, p. 322). A recent study assaying skeletal samples from a broad swath of sub-Saharan Africa had success with 20 cases out of 57 sampled skeletons (Wang et al. 2020). To date, not all lab groups publishing African aDNA results include information about human disease resistance genes. As the palaeogenomics field progresses, its outputs should be designed to provide not only information about population relationships but also information about peoples' resistance to pathogens in their environments (Marciniak and Perry 2017, p. 668). Like the explorations of disease resistance in animals (cf. bovine trypanosomiasis in African cattle), human disease resistance is relevant to archaeological topics. However, it seems unlikely that maladies known to have jumped from non-humans to humans in Africaincluding the Ebola virus, HIV, and probably others that have disappeared - will be amenable to palaeogenomic study.

In sum, the profile of past epidemic events in Africa is likely to differ from that seen in cooler regions of the world. Warmer temperatures mitigate against long periods spent in confined, shared indoor spaces, wearing layers of clothing for insulation. Subsistence patterns of foraging, pastoralism, and even farming may have been amenable to a strategy of abandoning a site at which disease befell the group. Although constrained by factors like resource availability and soil fertility, most African communities were nevertheless mobile, as shown by the Bantu expansion and other mobility patterns in the African past. If a virulent new pathogen were to arise in a more permanent settlement context, there might have been less flexibility. However, reconstructions of the challenges faced by ancient urban centers like Aksum and Great Zimbabwe focus on sociopolitical and environmental factors (Sulas and Pikirayi 2018), rather than diseases. While epidemics may have been very rare, there is evidence that endemic diseases like malaria, sleeping sickness, and schistosomiasis may have had substantial effects on peoples' decisions about where to live and how to organize their communities. 
The impact of disease should be weighed seriously as a variable when we muse about the patterns revealed by archaeology in Africa.

\section{References}

Anderson, J. E. (1968). Late Paleolithic skeletal remains from Nubia. In F. Wendorf (Ed.), The prehistory of Nubia (Vol. 2, pp. 996-1040). Dallas: Southern Methodist University.

Brunson, K., \& Reich, D. (2019). The promise of paleogenomics beyond our own species. Trends in Genetics, 35(5), 319-329. https://doi.org/10.1016/j.tig.2019.02.006.

Campbell, T. J., Stone, A. C., \& Ackermann, R. R. (2013). Investigating the emergence of tuberculosis in South Africa. American Journal of Physical Anthropology, 150, 93-93.

Darton, Y., Richard, I., \& Truc, M. C. (2013). Osteomyelitis variolosa: A probable mediaeval case combined with unilateral sacroiliitis. International Journal of Paleopathology, 3(4), 288-293. https://doi.org/10.1016/j.ijpp.2013.05.008.

Galagan, J. E. (2014). Disease mechanisms: Genomic insights into tuberculosis. Nature Reviews Genetics, 15(5), 307-320.

Gibbon, V. E., Gallagher, A., \& Huffman, T. N. (2014). Bioarchaeological analysis of Iron Age human skeletons from Zambia. International Journal of Osteoarchaeology, 24(1), 100-110. https://doi.org/10.1002/oa.2231.

Ho, S. Y. W., \& Duchêne, S. (2020). Dating the emergence of human pathogens. Science, 368(6497), 1310-1311.

Lahr, M. M., Rivera, F., Power, R. K., Mounier, A., Copsey, B., Crivellaro, F., . . Foley, R. A. (2016). Inter-group violence among early Holocene hunter-gatherers of West Turkana, Kenya. Nature, 529(7586), 394-+. https://doi.org/10.1038 /nature16477.

Marciniak, S., \& Perry, G. H. (2017). Harnessing ancient genomes to study the history of human adaptation. Nature Reviews Genetics, 18(11). https://doi.org/10.1038/nrg.2017.65.

Owers, K. A., Sjodin, P., Schlebusch, C. M., Skoglund, P., Soodyall, H., \& Jakobsson, M. (2017). Adaptation to infectious disease exposure in indigenous Southern African populations. Proceedings of the Royal Society B-Biological Sciences, 284(1852). https://doi.org/10.1098 /rspb.2017.0226.

Pfeiffer, S., Harrington, L., \& Lombard, M. (2019). The people behind the samples: Biographical features of past huntergatherers from KwaZulu-Natal who yielded aDNA.
International Journal of Palaeopathology, 24, 158-164. https://doi.org/10.1016/j.ijpp.2018.10.008.

Phillipson, D. W. (2005). African archaeology (3rd ed.). Cambridge: Cambridge University Press.

Pinhasi, R., Fernandes, D., Sirak, K., Novak, M., Connell, S., Alpaslan-Roodenberg, S., . . . Hofreiter, M. (2015). Optimal ancient DNA yields from the inner ear part of the human petrous bone. PLoS ONE, 10(6). https://doi. org/10.1371/journal.pone.0129102.

Prendergast, M. E., \& Sawchuk, E. (2018). Boots on the ground in Africa's ancient DNA 'revolution': Archaeological perspectives on ethics and best practices. Antiquity, 92(363), 803815. https://doi.org/10.15184/aqy.2018.70.

Rascovan, N., Sjogren, K. G., Kristiansen, K., Nielsen, R., Willerslev, E., Desnues, C., \& Rasmussen, S. (2019). Emergence and spread of basal lineages of Yersinia pestis during the Neolithic Decline. Cell, 176(1-2), 295-+. https://doi.org/10.1016/j.cell.2018.11.005.

Roberts, C. A., \& Buikstra, J. E. (2003). The bioarchaeology of tuberculosis: A global view on a reemerging disease. Gainesville: University Press of Florida.

Schlebusch, C. M., Malmström, H., Günther, T., Sjödin, P., Coutinho, A., Edlund, H., . . . Jakobsson, M. (2017). Southern African ancient genomes estimate modern human divergence to 350,000 to 260,000 years ago. Science, 358 , 652-655.

Stojanowski, C. M., Seidel, A. C., Fulginiti, L. C., Johnson, K. M., \& Buikstra, J. E. (2016). Contesting the massacre at Nataruk. Nature, 539(7630), E8-E10. https://doi.org/10.1038 /nature19778.

Sulas, F., \& Pikirayi, I. (Eds.). (2018). Water and society from ancient times to the present: Resilience, decline and revival. London: Routledge.

Wang, K., Goldstein, S., Bleasdale, M., Clist, B., Bostoen, K., Bakwa-Lufu, P., . . S Schiffels, S. (2020). Ancient genomes reveal complex patterns of population movement, interaction, and replacement in sub-Saharan Africa. Science Advances, 6(24), eaaz0183. https://doi.org/10.1126/sciadv.aaz0183.

Wendorf, F. (1968). Site 117: A Nubian final Paleolithic graveyard near Jebel Sahaba, Sudan. In F. Wendorf (Ed.), The prehistory of Nubia (Vol. 2, pp. 954-995). Dallas: Southern Methodist University.

Publisher's Note Springer Nature remains neutral with regard to jurisdictional claims in published maps and institutional affiliations. 